\title{
Snowball Education Method Effect the Family Support for Plwha Art's Adherence
}

\author{
Oktovina Mobalen ${ }^{1}$, Yowel Kambu ${ }^{1}$ \\ ${ }^{1}$ Lectures of Nursing Departement at Sorong Ministry Health Polytechnic
}

\begin{abstract}
Absract
HIV/AIDS epidemic nowadays has become as global effects, even if the prevention efforts still goes to conducted and improved. The aim of research was to knowing the effect of snowball method toward family support role in PLWHA ARV adherence. The research method used is quasy experiment with pre-posttest one group only design with the purposive sampling technique. Research results showed from 20 respondents were found at Malawei Public Health Center of Sorong City was that there are differentiation of mean values between pre-postest are 8,09 and standard deviation values are $-0,49$ and the Wilcoxon statistical test results was that the $\mathrm{p}$ values equal to 0,000 which mean there is a significant effect of the snowball method toward family support role in PLWHA ART's adherence. The snowball as the teaching method technique could be implemented in order to HIV/AID knowlege update and improves the PLWHA ART's adherence.
\end{abstract}

Keywords: snowball method, family support, PLWHA.

\section{Introduction}

Human Immunodeficiency Virus (HIV) /Acquired Immunodeficiency Syndrome (AIDS) now has become as a global impact. The World Health Organization (WHO) noted that since AIDS was discovered until 2015, there were 1.1 million people died, 2.1 million people were infected with HIV and 36.7 million people were living with $\mathrm{HIV}^{1}$.

Indonesia is the Asian country with the fastest developing HIV epidemic. Until the end of 2009, it was estimated that there were 186,257 PLWHA (15-49 years) spread across 33 provinces in Indonesia ${ }^{3}$. Data from the Sorong City Health Office 2016 shows that 1,519 cases were identified as reactive ( $\mathrm{HIV}+$ ) with 459 cases undergoing ART and 80 cases failing to follow up $^{6}$. Data from the Sorong City Malawei Health Center from January to December 2017 recorded 42 active people taking ARVs and 13 people stopping treatment ${ }^{7}$.
The snowball method is a modification of the educational technique by asking to focus on the ability to make questions that are packaged in an interesting game such as throwing paper that is rolled round like a snowball containing questions to fellow friends. This method explains how knowledge is generated, starting with a thought that gathers new perspectives and through the growth of richer collective knowledge ${ }^{9,10}$.

Family support can be a factor in determining individual health beliefs and values and determining the treatment program they will receive, providing support and making decisions regarding care of sick family members, especially PLHA who are isolated from the assistance of others related to adherence ${ }^{12}$.

\section{Method}

The research method used is Quasi Experiment with non-equivalent control group design using pre-posttest one group only sampling technique using Wilcoxon hypothesis test. 


\section{Results}

Table 1. The Frequency Distributions of Respondent Characteristics based on demographic data.

\begin{tabular}{|c|c|c|c|}
\hline & teristics & Frequencies & Percentage \\
\hline \multicolumn{4}{|c|}{ Ages: } \\
\hline- & Teenager & 2 & 10 \\
\hline- & Early adulthood & 7 & 35 \\
\hline- & Late adulthood & 9 & 45 \\
\hline- & Elderly & 2 & 10 \\
\hline \multicolumn{4}{|c|}{ Sex: } \\
\hline- & Male & 10 & 50 \\
\hline- & Female & 10 & 50 \\
\hline \multicolumn{4}{|c|}{ Formal Education Status: } \\
\hline- & None & 1 & 5 \\
\hline- & Low Formal Education & 4 & 20 \\
\hline- & Midlle Formal Education & 14 & 70 \\
\hline- & High Formal Education & 1 & 5 \\
\hline \multicolumn{4}{|c|}{ Tribe: } \\
\hline- & Papua & 7 & 35 \\
\hline- & Moluccas & 9 & 45 \\
\hline- & Java & 2 & 10 \\
\hline- & Sulawesi & 2 & 10 \\
\hline \multicolumn{4}{|c|}{ Occupation: } \\
\hline- & None & 11 & 55 \\
\hline- & Civil duty/an army/police & 0 & 0 \\
\hline- & Work for company & 7 & 35 \\
\hline- & Private & 2 & 10 \\
\hline \multicolumn{4}{|c|}{ Long HIVs Diagnosed: } \\
\hline- & $<1$ years & 2 & 10 \\
\hline- & $1-6$ years & 16 & 80 \\
\hline- & $>6$ years & 2 & 10 \\
\hline
\end{tabular}




\section{Table Explanation:}

Table 1 shows that the highests respondents distributions are the late adulthood (45\%), midlle formal education (70\%), Moluccas tribe (45\%), none occupation (55\%) and has 1-6 years HIV diagnosed (80\%) and the lowests are teeneger and elderly $(10 \% \mathrm{vs} 10 \%)$, none formal education and highest formal education (10\% vs $10 \%)$, both Java and Sulawesi tribes (10\%vs 10\%), civil duty/an army/police $(0 \%)$ and $<1$ years and $>6$ years HIV diagnosed (10\% vs $10 \%)$. However, there is no any proportion differenttation between male and famale (50\% vs $50 \%)$.

Table 2. The Wilcoxon hyphotesis test of Snowball Method.

\begin{tabular}{|l|l|l|l|l|l|}
\hline Family Support role & Mean & SD & SE & p value & N \\
\hline - Before & 13,65 & 4,73 & 0,51 & & \multirow{2}{*}{0,00} \\
\cline { 1 - 6 } - After & 21,74 & 3,24 & 0,51 & & 20 \\
\hline
\end{tabular}

\section{Table Explanation:}

From the tabel 2 as we see that the mean value before intervention is 13,65 with the SD 4,73 and after intervention is 21,74 with the SD 3,24. The before dan after mean values differentiations are 8,09 dan the SD are $-1,49$. the Wilcoxon test result is equal 0,000 , which is mean there is a significant effect of the snowball education method toward the family support role.

\section{Discussions}

The support role of family members remains as an important central part of the initial bastion for PLWHA. The phenomenon of discrimination and stigmatization turns out to be possible for people closest to PLWHA, even by health professionals in various health service units. Coupled with the problem of the still weak coordination of program implementation in various sectors, especially related to the rights of PLHA who have not been proportionately integrated ${ }^{6}$. This will affect PLHA to become depressed, thus triggering a decline in the PLWHA's health status and if it not treated quickly and appropriately could be fatal.

Despite its central role, many PLHA families refused to join in this study for various complex reasons. Some of the reasons that are often expressed are still feeling shy and have not dared to be open up to public. Researchers assume this is due to the high stigmatization both internally from within themselves, as well as externally originating from other families and communities and the assumption that HIV infection is caused by sexual anormative behavior. It turns out also, from the interviews of researchers with case managers of health services center and the hospitals, it is still found that PLHA and their families themselves do not want to open his/her HIV status to their closest people such as husbands, wifes, parents and other closest family members. This will certainly have an impact on the difficulty of reaching health services and the severed role of the family members in order to maintaining the health status of PLWHA.

The study results indicate that there is a significant effect on the application of the snowball method to increase knowledge of the role of family support in PLWHA's adherence. this means that family education and PLWHA can be applied using snowball method. With this technique, an audience that initially only discusses a particular topic in a small group, for example in this study the topic of discussion about PLWHA's ARV adherence, is gathered into a larger group to interactively discuss the same topic to equalize perceptions among discussion groups after being directed by the guider. The knowledge of ODHA families will be further enriched and deepened, rather than the using the classical educational method which is only done in one direction and ends with questions/ discussion without optimal audience involvement.

The similar research results are in line from Siboro (2013), about the effect of family support on the social functioning of PLWHA in Caritas PSE Medan shelter 
using analytic observation methods based on statistical tests calculating Spearmen rank correlation coefficient $\left(r^{\prime}=0.67\right)$ on 50 respondents showing the existence of the effect of family support on the social functioning of people with $\mathrm{PLWHA}^{6}$. Another research of $\mathrm{Li}$, et al. (2004) also showed that PLWHA desperately need help and family support because the condition of chronic diseases experienced requires comprehensive treatment ${ }^{7}$. Family support have a positive impact on improving the PLWHA's quality of life ${ }^{7}$. The existence of a family member who is chronically ill will certainly cause tension and hopelessness that lasts long and is very influential on the condition of family member who suffer from illness ${ }^{7}$.

From the literature search results, researchers did not found an identical study related to the effect of the snowball education method on increasing knowledge of the role of family support in PLWHA adherence. However, in practice the snowball method has been widely adopted and applied by teachers and lecturers in learning classes for a variety of purposes, particularly in evaluating student activity and for developing ideas on the main ideas of the topic ${ }^{9,10}$. The snowball method can be applied by forming small groups of 4-6 members per group. Formed circle formations in the group to make it look easier in the interaction look natural. The resource person designs the same theme given to each groups. Then each group member are given a paper to write their first thoughts about the theme set on a paper. Thoughts must be expressed in a few sentences but must remain clear enough, so that other members can also understand what the group members mean when writing it. When everyone has written down their ideas about the topic given, each member gives his/her paper to the group members on their right side, then the member who receives the paper rewrites his/her opinion on the same topic. The opinions could be contain various things, for example challenges and/or questions that respond to the opinions of the group members beforehand. Thought ideas written by group members then aim to develop existing thought ideas. After the second group member finishes writing their opinions, the paper is given again to the group members to the right, and so on. This cycle continues until the first member writer gets back the paper. Example: for identifying the mapping of group members' understanding, the exercise were given by the questions as follows: what do you think and understand about ART's adherence?; how should the solution be sought for PLWHA who have ART's dropped out?; what are your arguments about your friend's opinion about ART's droop out? Etc ${ }^{8,9,10}$.

It is clear that the role of family support for PLWHA cannot be doubted, if the method of educating related topics is transferred through the snowball education approach in peer group visits every month and or involving PLWHA families in certain gathering forums. If we look at the characteristics of PLWHA, most of those were Papuans and Moluccas ethnic, we need to specify the health education approach who touches on the cultural sphere so that more informative related to HIV/AIDS can be internalized effectively and efficiently without any patronizing elements that are more autocratic. The snowball education method were more flexible in its application in small and large groups, so that it can trigger the exploration of knowledge and understanding of PLWHA in peer groups. So, it will be very conducive to increase the knowledge of PLWHA families, even PLWHA themselves will have a very positive impact on improving PLWHA's quality of life.

PLWHA with supportive support have an opportunity to improve their quality of life. Family support are one of the factors affecting the quality of life of PLHWA ${ }^{13}$. Family support has been become as a factor that could be influence the determination of individual health beliefs and values and determine the treatment program that received by PLHWA. The family provides support and makes decisions regarding the care of sick family members as well ${ }^{13-16}$.

\section{Conclusion}

There is an effect of the snowball education method toward the family supports role for PLWHA ART's adherence at the Malawei public health center of Sorong City.

\section{Recomendation}

Familiy can further encourage PLWHA to participate in peer support groups in order to update their knowledge and improve family relationships which incidentally is very important in building the confidence of PLWHA. Family member of PLWHA can also initiate a PLWHA family forum adapted to the situation and condition of 
family member to strengthen support for PLWHA to maintain ART compliance and quality of life pattern with the support of authorized health workers.

\section{Disclaimer Statement}

Acknowledgment The authors acknowledge the head of Sorong City public health center for the research approval and to the research participants who have been involved.

Funding This research was supported by the government fund through the Sorong Health Polytechnic institution.

Conflicts of Interest No conflict of interest were complained by those who involved in this research.

\section{References}

1. KPAN (Komisi Penanggulangan HIV/AIDS Nasional), Situasi HIV dan AIDS di Indonesia. Depkes RI, KPA. 2009.

2. KPAN (Komisi Penanggulangan HIV/AIDS Nasional), Info HIV dan AIDS. Jakarta. 2010.

3. Dinas Kesehatan Kota Sorong, Data Pasien HIV/ AIDS. Sorong. 2016.

4. Puskesmas Malawei, Pasien HIV/AIDS. Sorong. 2017.

5. Tri Johan Agus, dkk. Peran Kelompok Dukungan Sebaya (KDS) dan Kepatuhan Minum Obat Pada ODHA Tahun 2014. Jurnal Pendidikan Kesehatan 2014; Vol 4, No 1 April 2015.

6. Siboro, H. K. Pengaruh Dukungan Keluarga Terhadap Keberfungsian Sosial ODHA di Rumah Singgah Caritas PSE Medan. 2013.

7. Kusuma, H. Hubungan Antara Depresi dan Dukungan Keluarga Dengan Kualitas Hidup Pasien HIV/AIDS yang menjalani Perawatan di RSUP Cipto Mangunkusumo JakARVa. Tesis. JakARVa: FIK-UI. 2011.

8. Learning scoop the snowball method. http:// learningscoop.fi/wp-content/uploads/2015/09/ Snowball-Method.pdf diakses tanggal 25 Agustus 2018.
9. Burk, I. The snowball questioning method. The Science Teacher, 2018; 79(4), 64-65. Retrieved from https://e-resources.perpusnas.go.id:2057/ docview/1017897404? accountid=25704 diakses tanggal 25 Agustus 2018.

10. Zahedi, R. Small group teaching in library and information science.Library Philosophy and Practice, , 2009; 1-6. Retrieved from https://e-resources.perpusnas.go.id:2057/ docview/224121216? accountid $=25704$ diakses tanggal 25 Agustus 2018.

11. Kambu, Y. Analisis Faktor-Faktor Yang Mempengaruhi Tindakan Pencegahan Penularan HIV oleh ODHA di Sorong. Tesis. Depok: Program Pasca Sarjana Fakultas Ilmu Keperawatan Universitas Indonesia. 2012.

12. Friedman, MM, Bowden, $\mathrm{O}$ \& Jones, $\mathrm{M}$. Keperawatan Keluarga : teori dan praktik. Jakarta. EGC. 1998.

13. Nurmalasari, Yanni. Hubungan antara Dukungan Sosial dengan Harga Diri pada Remaja Penderita Penyakit Lupus. Fakultas Psikologi: Universitas Gunadarma Jawa Barat. 2007.

14. Posmaningsih, D.A., Aryasih, G.A.M., Hadi, M.C., Marwati, N.M., Mallongi, A.. The influence of media booklet in behavior change of waste management in elementary school students, South Denpasar, Bali. Indian Journal of Public Health Research \& Development. 2018.

15. AB Birawida, M.Selomo and A. Mallongi, Potential hazards from hygiene, sanitation and bacterium of refill drinking water at Barrang Lompo, IOP Conference Series: Earth and Environmental Science, vol: 157, issue : 1, 2018-06-1, Conference Proceeding.

16. Endah Yani, R.W., Mallongi, A., Andarini, S., Prijatmoko, D., Dewanti, I.R. The effect of zinc saliva on the toddlers nutritional status, Journal of International Dental and Medical Research, 2016 vol: 9 , issue : 1 . 